Jusmal lemiah
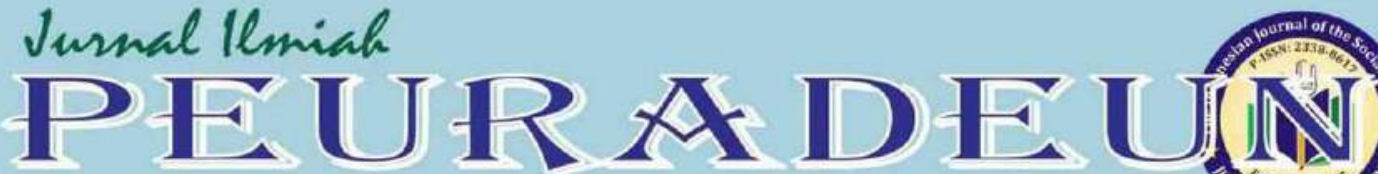

Vol. 8, No. 3, September 2020

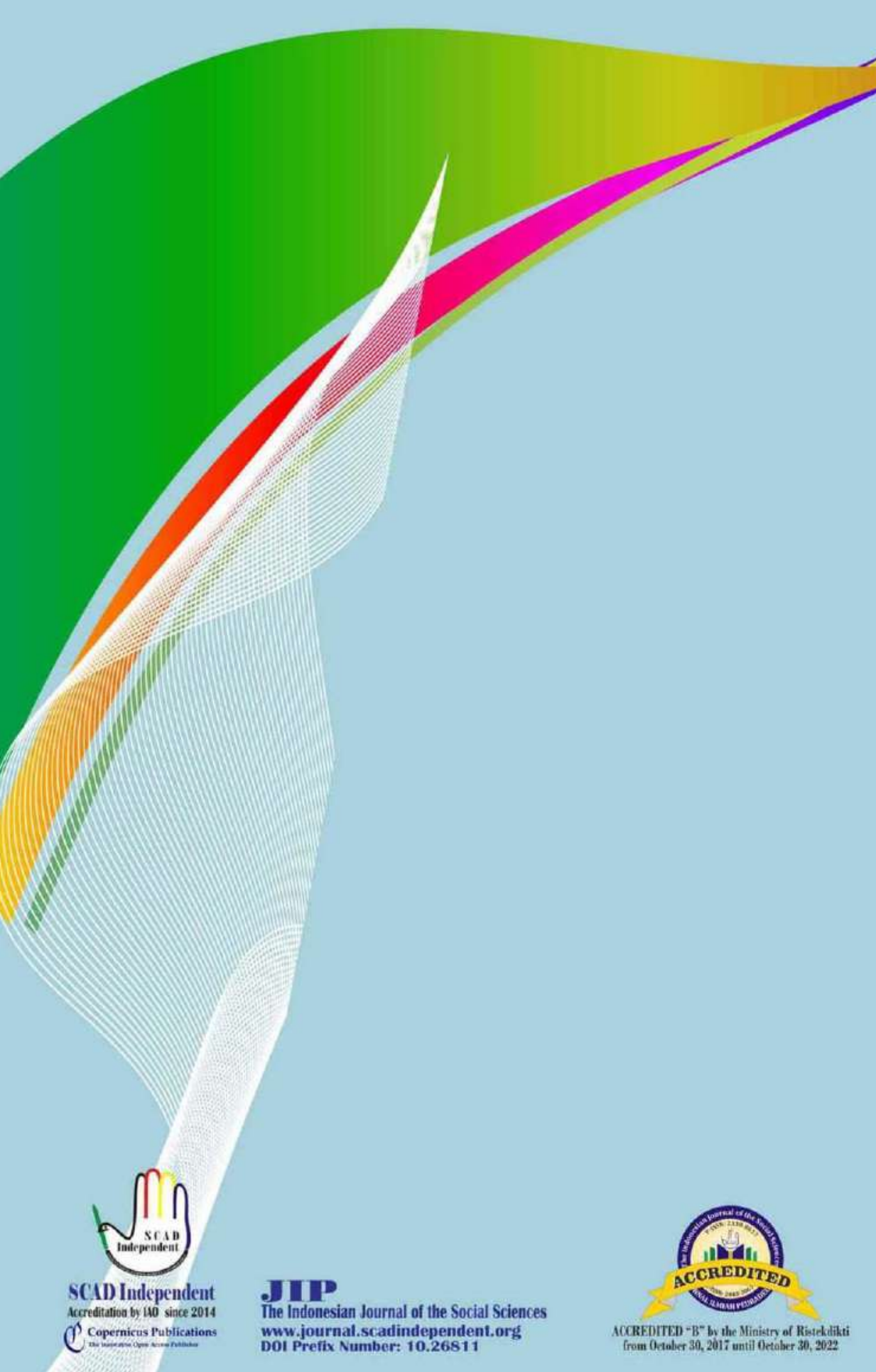

\section{Clarivate Analytics}

Emerging Sources Citation Index Web of Science ${ }^{\mathrm{TM}}$

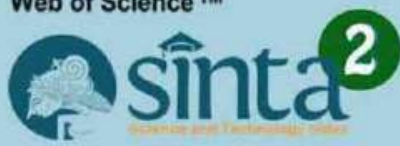

INDEX $\circledast$ COPERNICUS www.journal.scadindependent.org Dot Prefix Number: 10.2681 


\author{
JURNAL ILMIAH PEURADEUN \\ The Indanesian Journal of the Sacial Sciences \\ p-ISSN: 2338-8617/ e-ISSN: 2443-2067
}

www.journal.scadindependent.org

\author{
Vol. 8, No. 3, September 2020 \\ Pages: 521-530
}

\title{
Enhancing Moral Awareness for Racial Unity Through Islamic and Asian Civilization Course (TITAS): An Empirical Research from Non-Muslim Students' Perspective
}

\author{
Abu Zarrin Selamat ${ }^{1}$; Hafizul Fahri Hanafi ${ }^{2}$; Sakinah Salleh ${ }^{3}$; Aireen Aina \\ Bahari ${ }^{4}$; Mazarul Hasan Mohamad Hanapi ${ }^{5}$; Miftachul Huda ${ }^{6}$ \\ 1,3,6 Faculty of Human Science, Universiti Pendidikan Sultan Idris, Malaysia \\ ${ }^{2}$ Faculty of Arts, Universiti Pendidikan Sultan Idris, Malaysia \\ ${ }^{4}$ Faculty of Languages and Communications, Universiti Pendidikan Sultan Idris, Malaysia \\ ${ }^{5}$ Faculty of Human Development, Universiti Pendidikan Sultan Idris, Malaysia
}

\begin{abstract}
Article in Jurnal Ilmiah Peuradeun
Available at : https://journal.scadindependent.org/index.php/jipeuradeun/article/view/582

DOI $\quad$ : http://dx.doi.org/10.26811/peuradeun.v8i3.582
\end{abstract}

\section{How to Cite this Article}

APA : Selamat, A., Hanafi, H., Salleh, S., Bahari, A., Hanapi, M., \& Huda, M. (2020). Enhancing Moral Awareness for Racial Unity Through Islamic and Asian Civilization Course (TITAS): An Empirical Research from Non-Muslim Students' Perspective. Jurnal Ilmiah Peuradeun, 8(3), 521-530. doi:10.26811/peuradeun.v8i3.582

Others Visit : https://journal.scadindependent.org/index.php/jipeuradeun

Jurnal Ilmiah Peuradeun (JIP), the Indonesian Journal of the Social Sciences, is a leading peer-reviewed and openaccess journal, which publishes scholarly work, and specializes in the Social Sciences that emphasize contemporary Asian issues with an interdisciplinary and multidisciplinary approach. JIP is published by SCAD Independent and published 3 times of year (January, May, and September) with p-ISSN: 2338-8617 and e-ISSN: 2443-2067. Jurnal Ilmiah Peuradeun has become a CrossRef Member. Therefore, all articles published will have a unique DOI number. JIP has been accredited by the Ministry of Research Technology and Higher Education Republic of Indonesia (SK Dirjen PRP RistekDikti No. 48a/KPT/2017). This accreditation is valid from October 30, 2017 until October 30, 2022.

JIP published by SCAD Independent. All articles published in this journal are protected by copyright, licensed under a CC-BY-SA or an equivalent license as the optimal license for the publication, distribution, use, and reuse of scholarly works. Any views expressed in this publication are the views of the authors and not of the Editorial Board of JIP or SCAD Independent. JIP or SCAD Independent cannot be held responsible for views, opinions and written statements of authors or researchers published in this journal. The publisher shall not be liable for any loss, actions, claims, proceedings, demand, or costs or damages whatsoever or howsoever caused arising directly or indirectly in connection with or arising out of the use of the research material. Authors alone are responsible for the contents of their articles.

JIP indexed/included in Web of Science, MAS, Index Copernicus International, Sinta, Garuda, Moraref, Scilit, Sherpa/Romeo, Google Scholar, OAJI, PKP, Index, Crossref, BASE, ROAD, GIF, Advanced Science Index, JournalTOCs, ISI, SIS, ESJI, SSRN, ResearchGate, Mendeley and others. 


\title{
ENHANCING MORAL AWARENESS FOR RACIAL UNITY THROUGH ISLAMIC AND ASIAN CIVILISATION COURSE (TITAS):
}

\author{
An Empirical Research from Non-Muslim Students' Perspective
}

\author{
Abu Zarrin Selamat ${ }^{1}$; Hafizul Fahri Hanafi ${ }^{2}$; Sakinah Salleh ${ }^{3}$; Aireen \\ Aina Baharii'; Mazarul Hasan Mohamad Hanapi ${ }^{5}$; Miftachul Huda ${ }^{6}$ \\ 1,3,6Faculty of Human Science, Universiti Pendidikan Sultan Idris, Malaysia \\ ${ }^{2}$ Faculty of Arts, Universiti Pendidikan Sultan Idris, Malaysia \\ ${ }^{4}$ Faculty of Languages and Communications, Universiti Pendidikan Sultan Idris, Malaysia \\ ${ }^{5}$ Faculty of Human Development, Universiti Pendidikan Sultan Idris, Malaysia \\ ${ }^{1}$ Contributor Email: zarrin@fsk.upsi.edu.my
}

Received: Jun 20, 2020

Accepted: Sep 15, 2020

Published: Sep 30, 2020

Article Url: https://journal.scadindependent.org/index.php/jipeuradeun/article/view/582

\begin{abstract}
This article attempted to investigate the significance of the Islamic and Asian Civilization Course (TITAS) according to the point of view of non-Muslim students to form a harmonious view towards Islam besides forming and cultivating racial unity in Malaysia. This study was also conducted with expectations that TITAS will be the impetus to create moral awareness amongst non-Muslim students towards Islam and Muslims other than giving ideas that multiracial is assimilable through TITAS. This matter was aligned with the objective of the Islamic Civilization study for non-Muslim students and the goals of TITAS introduced in 1983. This study was conducted using a quantitative approach involving 203 non-Muslim students from Universiti Pendidikan Sultan Idris as the study sample. The mean was 3.81 which depicts a high-level achieverment of the goals and objectives of TITAS. This showed that TITAS was able and managed to predispose moral awareness amongst non-Muslim students towards Islam and Muslims. It is also proposed that TITAS continues to be maintained as the mainstream syllabus beyond the pre-university level.
\end{abstract}

Keywords: TITAS; Moral Awareness; Racial Unity; Non-Muslim Students 


\section{A. Introduction}

The study of Islamic and Asian Civilization (TITAS) is one of the courses introduced in Institute of Higher Education Malaysia (IPT) by the Ministry of Education Malaysia (KPM) in 1983 (Yatim, 1995), which then became a requirement in all IPT by 1997 (KPM, speech by the Minister of Education, 1997). The two initial objectives of the introduction of the study of Islamic and Asian Civilization in IPT were, first, to provide understanding to all IPT students about the role of Islam as one of the civilizations and ways of life in the world as well as its contribution to world civilization. Second, to extinguish doubts about Islam as the official religion of the country that may occur in a multiracial society. In this context, TITAS is viewed as one of the solutions to unite Malaysians who are of different ethnicities to achieve the country's vision of forming a nation-state as envisioned by all Malaysians. This is because the study of Islamic and Asian Civilization (TITAS) is a compulsory subject for all students regardless of their race and religion (Selamat, 2014).

According to Rahman and Sulaiman (1995), the objective of making the study of Islamic and Asian Civilization (TITAS) a requirement for non-Muslim students is to achieve two desires, the first is to expose non-Muslim students not only to Islamic civilization but to its achievements and system that once stood high in history, as well as its contribution to the world civilization. Second, to develop rational thinking and diminish fear, misunderstanding, and prejudice amongst non-Muslim students towards Islam, as a preparation to form a multiracial society in harmony and understanding, thus evoking non-Muslim students the status of Islam as the official religion of the country that needs to be respected.

Based on the two objectives mentioned above, it is clear that the mission and vision through education, specifically the study of Islamic and Asian Civilization (TITAS) is to achieve the goal of the National Education Philosophy (FPN) which is achieving a prosperous and 
harmonious multiracial society. The goal set in the National Education Philosophy is to produce better individuals who believe in God, knowledgeable and competent, who possess high moral standards, and able to contribute to the harmony and betterment of a multiracial society (Selamat, 2014). The values targeted in this goal of FPN show that the government, through education, is caring and concern about the efforts in producing moral-inducing elements amongst the multiracial society in Malaysia.

Today's daunting challenge in nurturing moral values in this globalization era is the lack of moral values such as respect, patriotism, teamwork, and others that are disappearing each day amongst Malaysians regardless of race, culture, language, and religion. Malaysians, especially teenagers prefer to follow and idolize Western trends like its fashion sense, entertainment, way of speaking, and many more negative trends from the West that demote the moral values, ethics, and aesthetics of Malaysian society.

The ongoing issue of the globalized hegemony that is getting out of hand these days has paved the way for the study of Islamic and Asian Civilization (TITAS) in becoming a required and significant subject in IPT. According to Bakar et. al (2009), the study of civilization becomes a beacon for students to be more and well-informed of the history of the many ethnicities in Malaysia. This is further explained by Za'ba (2009) who emphasized that the discussion of civilization has to be based on religion. For example, the Malay civilization is based on Islam which covers all aspects of human life. The objectives of the study are to:

1. Study the views of the non-Muslim students in UPSI towards the role of the study of Islamic and Asian Civilization (TITAS) in increasing moral awareness towards Islam and its believers.

2. Examine the role of the study of Islamic and Asian Civilization (TITAS) as the medium in producing a multiracial society with high moral values. 


\section{B. Literature Review}

According to the statistics in 2019, there were 32.6 million people in Malaysia, in which 29.4 million people were not citizens (Berita Harian Online, 2020) and the remaining were citizens. Amongst the citizens, 69.3 (20.4 million) percent were natives, 22.8 percent ( 6.7 million) were Chinese whereas 6.9 percent ( 2.03 million) were Indians and other races made up to 1.0 percent ( 0.29 million) of the number. Meanwhile, Islam dominated the religion composition in Malaysia in 2019 with 63.3 percent, followed by Buddhism with 19.8 percent, Christianity with 9.2 percent, Hinduism with 6.5 percent, other religions with 1.7 percent, and atheism making up to 0.5 percent (Wikipedia.org/wiki/Demografi_Malaysia).

The aforementioned statistics of race and religion composition in Malaysia clearly show that Malaysia is made up of multiple races. According to Zaharuddin (2014), the world views Malaysia as a unique country because of the various ethnicities. However, this uniqueness has brought upon several social issues that yearn for one solid and consistent system to maintain and protect the prosperity and harmony achieved. Education is one of the solid and consistent systems that can maintain and protect the prosperous and harmonious relationship between races. Tun Abdul Razak in his speech on 23rd January 1971 (Aziz, Sabri \& Nordin, 2014), stated that "the best way to nurture unity is through learning and education. The schools in our country have to be utilized as a farm in which the seeds of unity between races are cultivated".

Therefore, one of the subjects that have been meticulously planned and prepared by the government to achieve racial unity is the study of Islamic and Asian Civilization (TITAS). There are a few studies conducted by previous researchers who studied the contribution and role of the study of Islamic and Asian Civilization as the agent of racial unity.

\section{Method}

This study was conducted using a quantitative approach involving 203 non-Muslim students. The respondents were required to answer 21 questions regarding their views towards the study of Islamic and Asian 


\section{Abu Zarrin Selamat et al.}

Civilization (TITAS) as the catalyst of moral awareness towards Islam and its believers to develop racial unity amongst non-Muslim students. The decision to opt to quantitative approach was the right choice as it fits the research objectives which are to study the views of the non-Muslim students and Muslims and to examine the role of the study of Islamic and Asian Civilization (TITAS) in raising high moral awareness amongst nonMuslim students towards Islam and its believers.

\section{Result and Discussion}

Based on the results of data collection and data analysis used as samples in this study, namely as many as 203 non-Muslim students, the following results can be stated.

\begin{tabular}{|c|c|c|c|c|c|c|c|c|c|}
\hline Code & Item & $\begin{array}{l}\text { SD } \\
(\%)\end{array}$ & $\begin{array}{l}\mathrm{DA} \\
(\%)\end{array}$ & $\begin{array}{l}\text { KS } \\
(\%)\end{array}$ & $\begin{array}{l}\mathrm{Ttl} \\
(\%)\end{array}$ & $\begin{array}{c}\mathrm{A} \\
(\%)\end{array}$ & $\begin{array}{l}\text { SA } \\
(\%)\end{array}$ & $\begin{array}{l}\text { Ttl } \\
(\%)\end{array}$ & Mean \\
\hline \multirow[t]{2}{*}{ A1 } & \multirow{2}{*}{$\begin{array}{l}\text { Learning TITAS } \\
\text { balances and } \\
\text { harmonizes my } \\
\text { intellect }\end{array}$} & 2.5 & 5.4 & 27.1 & 35 & 50.7 & 14.3 & 65 & \multirow{2}{*}{3.6897} \\
\hline & & 5 & 11 & 55 & (71) & 103 & 29 & (132) & \\
\hline \multirow[t]{2}{*}{$\mathrm{A} 2$} & \multirow{2}{*}{$\begin{array}{l}\text { Learning TITAS } \\
\text { balances and } \\
\text { harmonizes my } \\
\text { spirit }\end{array}$} & 1.0 & 6.9 & 27.6 & 35.5 & 49.8 & 14.8 & 64.6 & \multirow{2}{*}{3.7044} \\
\hline & & 2 & 14 & 56 & (72) & 101 & 30 & (131) & \\
\hline \multirow[t]{2}{*}{ A3 } & \multirow{2}{*}{$\begin{array}{l}\text { Learning TITAS } \\
\text { balances and } \\
\text { harmonizes my } \\
\text { emotion }\end{array}$} & 2.5 & 6.9 & 28.1 & 37.5 & 47.3 & 15.3 & 62.6 & \multirow{2}{*}{3.6601} \\
\hline & & 5 & 14 & 57 & (76) & 96 & 31 & (127) & \\
\hline \multirow[t]{2}{*}{ A4 } & \multirow{2}{*}{$\begin{array}{l}\text { Learning TITAS } \\
\text { balances and } \\
\text { harmonizes my } \\
\text { physical }\end{array}$} & 3.0 & 5.9 & 29.6 & 38.5 & 46.8 & 14.8 & 61.6 & \multirow{2}{*}{3.6453} \\
\hline & & 6 & 12 & 60 & (78) & 95 & 30 & (125) & \\
\hline \multirow[t]{3}{*}{ A5 } & TITAS transforms & & & & & & & & \multirow{3}{*}{3.8818} \\
\hline & $\begin{array}{l}\text { me into an } \\
\text { individual who }\end{array}$ & 2.0 & 6.4 & 21.2 & 29.6 & 42.4 & 28.1 & 70.5 & \\
\hline & $\begin{array}{l}\text { believes in my } \\
\text { religion }\end{array}$ & 4 & 13 & 43 & (60) & 86 & 57 & (143) & \\
\hline A6 & TITAS transforms & 1.5 & 7.4 & 21.2 & 30.1 & 42.4 & 27.6 & 70 & 3.8719 \\
\hline
\end{tabular}


Vol. 8, No. 3, September 2020

me into an

$3 \quad 15 \quad 43$

(61)

$86 \quad 56$

(142)

individual who is

devoted to my

religion

A7 I wish to become a knowledgeable Malaysian after learning TITAS

$\begin{array}{cccccccc}1.5 & 3.4 & 20.7 & \mathbf{2 5 . 6} & 49.8 & 24.6 & \mathbf{7 4 . 4} & 3.9261 \\ 3 & 7 & 42 & \mathbf{( 5 2 )} & 101 & 50 & \mathbf{( 1 5 1 )} & \end{array}$

A8 I wish to become a competent

$\begin{array}{cccccccc}1.5 & 4.9 & 23.6 & \mathbf{3 0} & 50.7 & 19.2 & \mathbf{6 9 . 9} & \\ 3 & 10 & 48 & \mathbf{( 6 1 )} & 103 & 39 & \mathbf{( 1 4 2 )} & 3.8128\end{array}$
learning TITAS

A9 I wish to become a noble Malaysian $\begin{array}{lllllll}1.5 & 5.4 & 18.7 & 25.8 & 53.7 & 20.7 & \mathbf{7 4 . 4}\end{array}$ after learning TITAS

$3 \quad 11 \quad 38$

(52) 109

3.8670

A10 I wish to become a responsible

$\begin{array}{lllllll}1.0 & 5.9 & 20.7 & 27.6 & 53.7 & 18.7 & \mathbf{7 2 . 4}\end{array}$

Malaysian after learning TITAS

$2 \quad 12 \quad 42$

(56) 109

3.8325

A11 TITAS successfully transforms me into
a Malaysian who
$\begin{array}{lll}1.5 & 7.4 & 22.2\end{array}$
$\begin{array}{llll}31.1 & 49.3 & 19.7 & 69\end{array}$
wants to achieve

$3 \quad 15 \quad 45$
(63) $100 \quad 40$
(140)
3.7833
contribute to the
nation's harmony

A12 TITAS successfully transforms me into
a Malaysian who
wants to achieve
$1.5 \quad 5.4 \quad 27.6$
$\begin{array}{llll}34.5 & 48.3 & 17.2 & \mathbf{6 5 . 5}\end{array}$
self prosperity and
$3 \quad 11 \quad 56$
(70) $98 \quad 35$
3.7438
contribute to the
nation's prosperity

A13 TITAS successfully

provides an

understanding of

Islam as a

$\begin{array}{ccc}0.5 & 3.0 & 19.2 \\ 1 & 6 & 39\end{array}$

$22.7 \quad 55.7 \quad 21.7 \quad 77.4$

civilization 
Abu Zarrin Selamat et al.

A14 TITAS successfully

provides an

understanding of

$\begin{array}{lllllll}1.5 & 4.9 & 16.3 & 22.7 & 56.7 & 20.7 & 77.4\end{array}$

Islam as a

$3 \quad 10 \quad 33$

(46) $115 \quad 42 \quad$ (157)

3.9015

universal way of

life

A15 TITAS successfully contributes to world civilization

$1.5 \quad 6.9$

6.921

1.730 .1

$30.1 \quad 49.3 \quad 20.7 \quad 70$

$\begin{array}{lllllll}3 & 14 & 44 & \text { (61) } & 100 & 42 & \text { (142) }\end{array}$

3.8079

A16 TITAS successfully transforms me into an individual with rational thoughts

$\begin{array}{lllllll}1.0 & 5.9 & 22.2 & 29.1 & 54.2 & 16.7 & \mathbf{7 0 . 9}\end{array}$ on Islam

$\begin{array}{lllllll}2 & 12 & 45 & \mathbf{( 5 9 )} & 110 & 34 & \mathbf{( 1 4 4 )}\end{array}$

3.7980

I am no longer

afraid of Islam

after learning

TITAS

$\begin{array}{lllllll}2.0 & 9.9 & 22.7 & 34.6 & 46.8 & 18.7 & \mathbf{6 5 . 5}\end{array}$

$\begin{array}{lllllll}4 & 20 & 46 & \mathbf{( 7 0 )} & 95 & 38 & \mathbf{( 1 3 3 )}\end{array}$

3.7044

I do not have any

misunderstanding

on Islam after

learning TITAS

$\begin{array}{cccccccc}2.0 & 5.9 & 19.7 & \mathbf{2 7 . 6} & 52.2 & 20.2 & \mathbf{7 2 . 4} & \\ 4 & 12 & 40 & \mathbf{( 5 6 )} & 106 & 41 & \mathbf{( 1 4 7 )} & \end{array}$

A19 I do not have any

prejudice on Islam

$\begin{array}{llllll}5.9 & 25.6 & 31.5 & 48.3 & 20.2 & 68.5\end{array}$

after learning

TITAS

$\begin{array}{llllll}12 & 52 & \text { (64) } & 98 & 41 & \text { (139) }\end{array}$

3.8276

A20 TITAS successfully shapes me as a

$\begin{array}{lllllll}0.5 & 4.9 & 25.6 & 31 & 49.3 & 19.7 & \mathbf{6 9}\end{array}$

harmonious

$\begin{array}{lllllll}1 & 10 & 52 & \mathbf{( 6 3 )} & 100 & 40 & \mathbf{( 1 4 0 )}\end{array}$

3.8276

Malaysian

A21 TITAS reminds me

that Islam is the

official religion of

the country that

$\begin{array}{lll}0.5 & 5.4 & 22.2\end{array}$

$\begin{array}{llll}28.1 & 48.8 & 23.2 & 72\end{array}$

has to be respected

$\begin{array}{lllllll}1 & 11 & 45 & \mathbf{( 5 7 )} & 99 & 47 & \mathbf{( 1 4 6 )}\end{array}$

The findings from the questionnaire for item A1 to A21 proved that a majority of the non-Muslim students agreed that the study of 
Islamic and Asian Civilization (TITAS) has brought a positive impact towards their moral awareness in terms of personality, belief system, determination, views towards Islam and positive paradigm shift. The high mean score for each item which is between 3.6453 until 3.9505 shows that a consistent agreement towards the discussed items. This also proves that the respondents agreed that the objective of Islamic Civilization education for non-Muslim students is relevant to the goal of Islamic Civilization education introduced in 1983 and the National Education Philosophy. Furthermore, these findings show that the government's sincere intention and purpose in introducing the study of Islamic and Asian Civilization (TITAS) to all students is relevant. This is supported by the very high overall mean score which is 3.8072 .

This study is attempted to examine the valuable insights of TITAS on enhancing the more awareness for racial unity in disseminating the points of relevance through the non-Muslim perspective. In this view, the incorporation of having a mutual line of responsibility and patriotism should be brought to develop moral skills amongst the students across the diverse background.

TITAS with its distinctive points has been able to expand the management of individual and social development amongst non-Muslim students in understanding Islam and Muslims. With enhancing their moral awareness, TITAS continued to maintain the components of racial understanding towards diversity in the country, through providing syllabus with pre-university level.

\section{E. Conclusion}

The Islamic and Asian Civilization course (TITAS) course is established as a medium in developing moral values, a sense of responsibility, and the spirit of patriotism. This is aligned with the aspiration of the Ministry of Higher Education that prioritizes the 
Abu Zarrin Selamat et al.

inclusion of moral values, nationalism, understanding towards culture and civilization, self-awareness, and interaction skills amongst multiracial students as recorded in the Malaysia Education Development Plan 20152025.

Therefore, the TITAS course should be further improved and upheld as a compulsory subject in higher education institutes, be it public or private institutions in Malaysia. TITAS has become a relevant impetus in developing a nation-state specifically in globalizing students' values and culture. The exposure that students receive from studying civilizations helps to develop a sense of understanding and respect amongst Malaysians who are of different religions, races, ethnicity, and culture. This is such an important matter especially for the upcoming generation who will soon lead this country.

\section{Bibliography}

Ahmad Sabri. A.Z.S. (2014). Raksa Raya Malaysia. Bangi, Selangor: Institut Terjemahan \& Buku Malaysia Berhad.

Aziz, A.R.A., Sabri, A.Z.S.A. and Nordin, M.N.A. (2014). Ke Arah Pemupukan Dalam Kepelbagaian Masyarakat 1 Malaysia. Kuala Lumpur: Institut Terjemah \& Buku Malaysia Berhad.

Bakar, O., Baharudin, A. and Ahmad, Z. (2013). Modul Pengajian Tamadun Islam dan Tamadun Asia. Kuala Lumpur: Universiti Malaya.

Berita Harian Online, 8 Januari 2020:

https://www.bharian.com.my/berita/nasional/2019/07/585216/pendu duk-malaysia-dianggarkan-326-juta-pada-2019

Lewis, M., \& Ponzio, V. (2016). Character Education as the Primary Purpose of Schooling for the Future. Jurnal Ilmiah Peuradeun, 4(2), 137-146. doi:10.26811/peuradeun.v4i2.92

Rahman, R.A. and Sulaiman, G. (1995). Pengajaan Tamadun Islam Kepada Pelajar Bukan Islam Di Institut Teknoli MARA, Prosiding Seminar Isu-Isu Pendidikan Tamadun Islam, Bangi: Pusat Pengajian Umum, Universiti Kebangsaan Malaysia 
Selamat, A.Z. (2014). Kajian Kes Penilaian Pelaksanaan Kursus Tamadun Islam Dalam Kalangan Pelajar Bukan Islam Di Politeknik Zon Tengah, Tesis Doktor Falsafah: Universiti Sains Malaysia

Wikipedia.org/wiki/Demografi_Malaysia

Yatim, B. (1995). “Pengajaran Kursus Tamadun Islam di Pusat-Pusat Pengajian Tinggi Di Malaysia", Isu-Isu Pendidikan Islam Di Malaysia: Harapan dan Cabaran, Kuala Terengganu: Yayasan Islam Terengganu Sdn. Bhd.

Yusoff, M. Z. M., \& Hamzah, A. (2015). Direction of Moral Education Teacher To Enrich Character Education. Jurnal Ilmiah Peuradeun, 3(1), 119-132.

Za'ba. (2009). Mencapai Keluhuran Budi. Kuala Lumpur: Dewan Bahasa dan Pustaka.

Zawiah Hj. Mat. (2017). Keindahan Akhlak dan Adab Menurut Al-Quran dalam Al-Quran Memartabatkan Ilmu, Membumikan Titah Wahyu. Karya Suntingan oleh Omar, S.R., Sulaiman, N. Melaka: Universiti Teknikal Malaysia Melaka. 